\title{
Comparison of wheat yield and soil properties under open and poplar based agroforestry system
}

\author{
Neema Bisht", V. K. Sah, Kavita Satyawali and Salil Tiwari \\ Department of Agroforestry, College of Agriculture, G.B. Pant University of Agriculture \& Technology, Pantnagar \\ - 263145 (Uttarakhand),INDIA \\ *Corresponding author. E-mail: neemabishtagri@gmail.com
}

Received: October 6, 2016; Revised received: March 6, 2017; Accepted: July 31, 2017

\begin{abstract}
Field experiment was conducted during the Rabi season of 2013-14 on an established plantation at old site of Agroforestry Research Centre, Patharchatta of G.B. Pant University of Agriculture and Technology, Pantnagar, District Udham Singh Nagar, Uttarakhand, India to evaluate the effect of poplar based agroforestry system and open system (without poplar) on yield of different wheat varieties and soil physico-chemical properties. The experiment was laid out in randomized block design with 4 treatments and each replicated thrice under both the growing conditions. The crop treatments are wheat varieties viz. UP-2572, PBW-550, DBW-711 and PBW-373. The highest grain yield of all the wheat varieties was obtained under open farming system. Highest grain yield of wheat was recorded in UP-2572 (45.3 q/ha) under open farming system. Agroforestry is proven land use system for vertically enhancing soil health against unsuitable weather condition. The distribution of soil properties was detected from the depth $0-15 \mathrm{~cm}$ in poplar based agroforestry system and as well as in open system. During the experiment it was found that agroforestry add more nutrients to the soil compared to open system i.e. highest $\mathrm{pH}(7.9), \mathrm{EC}\left(0.43 \mathrm{dSm}^{-}\right.$ $\left.{ }^{1}\right)$, available soil nitrogen $(253.48 \mathrm{~kg} / \mathrm{ha})$, potassium $(219.63 \mathrm{~kg} / \mathrm{ha})$ were achieved with UP-2572 while organic carbon $(1.07 \%)$ and available soil phosphorus $(22.72 \mathrm{~kg} / \mathrm{ha})$ were attained with DBW-711.
\end{abstract}

Keywords: Agroforestry, Correlation, Nutrient, Variety, Yield

\section{INTRODUCTION}

Agroforestry is considered as a panacea for maladies of intensive agriculture. It not only prevents land degradation but also improves site productivity through interaction among trees, soil and crops and thus restores soil fertility (Kumar, 2006). It is a way out to practice agriculture without deteriorating agroecosystem. Its role in the light of combating hunger, disease and environmental degradation is highly appreciable (Garrity, 2004). Wheat (Triticum aestivum L.) is widely intercropped cereal crop during rabi season (November-April) with Poplar, Eucalyptus and other fast growing tree species in northern states of India viz., Uttarakhand, Punjab, Haryana, Uttar Pradesh and Bihar, parts of central and eastern states such as Madhya Pradesh, Chhattisgarh and West Bengal. Poplar and Eucalyptus are the most successful industrial agroforestry tree species in India with extremely high productivity up to $10-30 \mathrm{~m}^{3} / \mathrm{ha} / \mathrm{yr}$. Intercropping with high density short rotation tree species is the best option to meet increasing food and industrial raw material requirement through sustainable utilization of natural resources (Sarvadeet al.2014). Cropping with tree species is an ancient practice and very important tool to achieve goal of National Forest Policy (1988). It has been reported as an important component of the 'evergreen revolution' movement in the country (Puri and Nair, 2004).Poplar trees are characterized by higher rates of nutrient accumulation in soil through litter fall as compared to open system. Poplars are efficient in the cycling of nutrients and a large portion of nutrients utilized for annual growth of arable crops. The leaf fall contribute to the addition of organic matter as well as nutrient to soil (Bernier, 1984). The investigation was mainly carried out to determine the impact of agroforestry system on soil properties and yield of wheat as compared to open farming system.

\section{MATERIALS AND METHODS}

A field experiment was carried out during Rabi season of 2013-14 at old site of Agroforestry Research Centre, Patharchatta of G. B. Pant University of Agriculture and Technology, Pantnagar, District Udham Singh Nagar, Uttarakhand, India. The experiment was laid out in randomized block design with two growing conditions open (without trees) and intercropping with poplar clone (PH7 and $\mathrm{PH} 8$ ) and four varieties of wheat (UP-2572, PBW-550, DBW-711 and PBW-373) with three replications in each system. The clones of Populus deltoids viz., $\mathrm{PH} 7$ and $\mathrm{PH} 8$ were taken at $3.0 \times 7.0 \mathrm{~m}^{2}$ spacing during 2012. The wheat (Triticum aestivum L.), varieties was raised with the recommended cultural practices during 2013. The effect of poplar 
clone and open condition on wheat crop was estimated in terms of yield (straw and grain). Grain and straw yield $(\mathrm{q} / \mathrm{ha})$ was determined on the net plot $\left(3.0 \mathrm{~m}^{2}\right)$ area basis. Soil samples were collected after harvesting of the wheat crop from net plots at $0-15 \mathrm{~cm}$ depth for the study of nutrient status and physico-chemical properties viz., available nitrogen (by kjeldahl method using alkaline potassium permanganate), potassium (by flame photometer) and phosphorus (by Olsen's method), organic carbon (Walkley and Black's method), $\mathrm{pH}$ and EC was determined by following standard procedures (Jackson, 1967). The data recorded for the above parameters of both the clones were averaged. For growth performance of tree, tree height and diameter at breast height $(\mathrm{dbh})$ was measured at sowing time of wheat, 30, 60, 90 days after sowing of wheat crop and at harvest. The tree parameters for both the clones were recorded separately.

\section{RESULTS AND DISCUSSION}

Crop yield: Grain and straw yield of wheat was decreased under fast growing short rotation tree species (PH 7 and PH 8) as compared to open condition (Table 1). Maximum grain and straw yield was registered under the open condition. Grain yield was significantly affected by the different varieties of wheat under both open and closed condition, whereas straw yield were non- significant. The variety (UP-2572) recorded highest grain (45.3 and $41.3 \mathrm{q} / \mathrm{ha}$ ) and straw (77.0 and 68.3 $\mathrm{q} / \mathrm{ha}$ ) yield in open and poplar based system, respectively which was closely followed by PBW-550,DBW711 and PBW-373.

Light, moisture and nutrients are the most important limiting factors which influence the overall growth and yield of agroforestry systems. Significant yield reduction by tree species could be due to their shading effect and below ground competition for resources. Allelopathic effect is important cause of crop yield reduction in agroforestry systems (Prasad et al., 2010). The loss of yield, however, was not only due to the growth of trees but also due to the loss of land area to trees. There are other numerous reasons for reduction in yield under canopy. Whereas, the other half of yield reduction is due to the competition between the tree and crop for light, moisture, nutrients, etc. and the modification of micro environmental conditions. The reduced wheat grain yields in the agroforestry treatments relative to

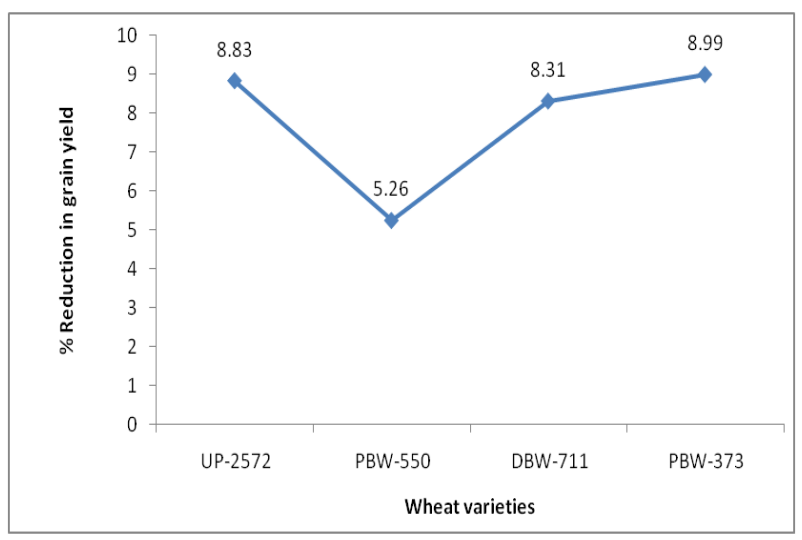

Fig. 1: Per cent reduction in grain yield of wheat under poplar compared to open system.

sole wheat demonstrate the existence of competition, as reported by Sarvade et al.(2014). Under poplar system, the minimum percent reduction in grain yield (5.26\%) was achieved with PBW 550 while PBW 373 recorded maximum reduction percent $(8.99 \%)$ as compared to open system (Fig. 1).

Soil physico-chemical properties: Soil physicochemical properties (viz., pH, EC and organic carbon percent)were not significantly affected by different varieties of wheat as well as both the conditions (open and poplar plantation). The soil $\mathrm{pH}$ and EC was lowered under open condition compared to poplar interfaces. The greater $\mathrm{pH}$ in tree based land use system could be due to humic matters released as a result of tree root exudates that complex the aluminum $\left(\mathrm{Al}^{+3}\right)$ and consequently result in greater soil $\mathrm{pH}$, especially in acidic soil while higher EC under poplar system may be due to production of organic acids from decomposition of litter and the effect of climatic variables viz. solar radiation, temperature, relative humidity, precipitation and wind velocity (Newaj et al., 2007). The highest $\mathrm{pH}$ and EC was recorded under the variety UP 2572 under poplar interface while the lowest was obtained with the same variety in open condition. Highest organic carbon was recorded from Poplar interfaces. High organic matter content in the intercropping treatment could be ascribed to the fact that leaf fall before and during crop sowing period on the soil which incorporates in to the soil through tillage practices and their partial decomposition adds to the soil organic matter. These results are similar with the results reported by Gupta and

Table 1. Effect of land use system on yield of wheat crop.

\begin{tabular}{lccccc}
\hline \multirow{2}{*}{ Treatment } & \multicolumn{2}{c}{ Grain yield $(\mathbf{q} / \mathbf{h a})$} & & \multicolumn{2}{c}{ Straw yield $(\mathbf{q} / \mathbf{h a})$} \\
\cline { 2 - 3 } \cline { 5 - 6 } & Open & Poplar & & Open & Poplar \\
\hline UP-2572 & 45.3 & 41.3 & & 77.0 & 68.3 \\
PBW-550 & 38.0 & 36.0 & & 73.7 & 52.3 \\
DBW-711 & 31.3 & 28.7 & & 67.7 & 50.0 \\
PBW-373 & 26.7 & 24.3 & & 65.0 & 50.7 \\
SEm \pm & 1.9 & 0.9 & & 5.5 & 4.9 \\
CD at 5\% & 6.4 & 3.2 & & NS & NS \\
\hline
\end{tabular}


Table 2. Correlation coefficient among soil parameters and yield in open condition.

\begin{tabular}{|c|c|c|c|c|c|c|c|}
\hline Characters & $\begin{array}{l}\text { Soil EC } \\
\left(\mathrm{dSm}^{-1}\right)\end{array}$ & $\begin{array}{c}\text { Soil } \\
\text { organic car- } \\
\text { bon }(\%) \\
\end{array}$ & $\begin{array}{c}\text { Available } \\
\text { soil N (kg/ } \\
\text { ha) }\end{array}$ & $\begin{array}{c}\text { Available } \\
\text { soil } \mathrm{P}_{2} \mathrm{O}_{5} \\
(\mathrm{~kg} / \mathrm{ha}) \\
\end{array}$ & $\begin{array}{c}\text { Available } \\
\text { soil } \mathrm{K}_{2} \mathrm{O} \\
(\mathrm{kg} / \mathrm{ha}) \\
\end{array}$ & $\begin{array}{c}\text { Grain } \\
\text { yield (kg/ } \\
\text { ha) }\end{array}$ & $\begin{array}{c}\text { Straw } \\
\text { yield (kg/ } \\
\text { ha) } \\
\end{array}$ \\
\hline Soil pH & .354 & .308 & -.881 & .111 & -.656 & .237 & .263 \\
\hline Soil EC $\left(\mathrm{dSm}^{-1}\right)$ & & .302 & -.175 & -.883 & -.826 & -.141 & -.010 \\
\hline Soil organic carbon $(\%)$ & & & .215 & -.050 & -.432 & -.851 & -.832 \\
\hline Available Soil N (kg/ha) & & & & -.182 & .409 & -.706 & -.718 \\
\hline Available Soil $\mathrm{P}_{2} \mathrm{O}_{5}(\mathrm{~kg} / \mathrm{ha})$ & & & & & .541 & .142 & .014 \\
\hline Available Soil $\mathrm{K}_{2} \mathrm{O}$ (kg/ha) & & & & & & .106 & .009 \\
\hline Grain Yield (kg/ha) & & & & & & & $.991 * *$ \\
\hline
\end{tabular}

Sharma 2009. The DBW 711 (1.07\%) variety of wheat recorded higher organic carbon under poplar condition while in open condition it was with UP 2572 (0.97\%). The variety PBW 550 recorded higher EC under both the conditions whereas lower electrical conductivity recorded with DBW 711(Fig. 2).

Soil nutrient status: Available soil $\mathrm{N}, \mathrm{K}_{2} \mathrm{O}$ and $\mathrm{P}_{2} \mathrm{O}_{5}$ were non-significantly influenced by both the condition open and intercropping of wheat with poplar (Fig: 3 ). The highest available soil $\mathrm{N}, \mathrm{P}_{2} \mathrm{O}_{5}$ and $\mathrm{K}_{2} \mathrm{O}$ were recorded under intercropping of wheat with poplar. Nutrients are made available to plants in agroforestry mainly by atmospheric nitrogen fixation and mineralization of nutrients from organic forms (Hymavathi et

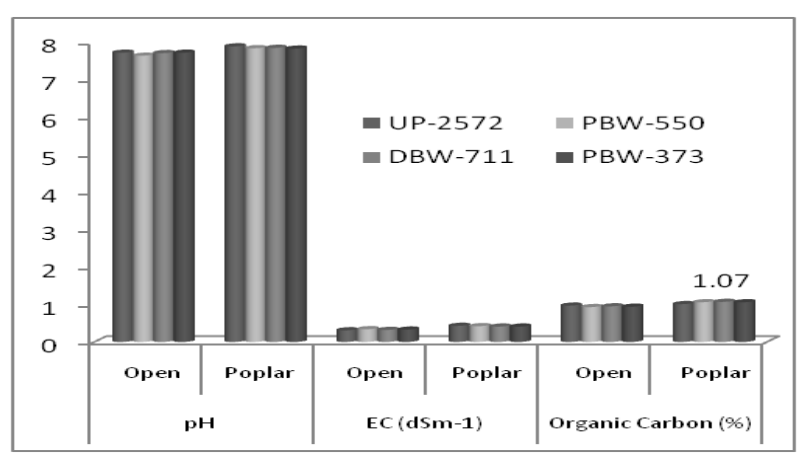

Fig. 2: Effect of land use system on soil physico chemical properties.

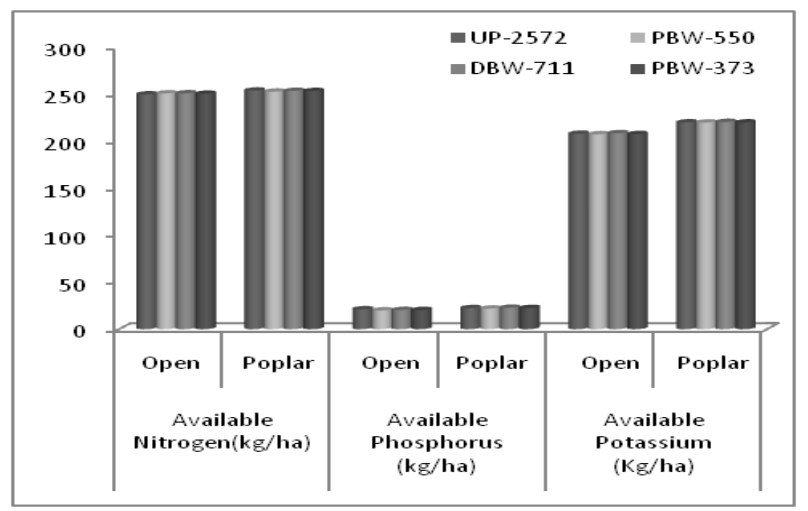

Fig. 3: Effect of land use system on soil nutrient status. al., 2010). The intercropping of trees with crops that are able to biologically fix nitrogen is common in tropical agroforestry systems. Non $\mathrm{N}$-fixing trees can also enhance soil physical, chemical and biological properties by adding significant amount of organic matter and releasing and recycling of nutrients in agroforestry systems (Antonio and Gama-Rodrigues, 2011). Different varieties of wheat with poplar showed nonsignificant effect on the soil available nutrients. Under intercropping system of wheat with poplar, wheat variety UP 2572 recorded highest available soil N (253.48 $\mathrm{kg} / \mathrm{ha})$ and $\mathrm{K}_{2} \mathrm{O}(219.63 \mathrm{~kg} / \mathrm{ha})$ whereas $\mathrm{P}_{2} \mathrm{O}_{5}(22.72 \mathrm{~kg} /$ ha) was maximum with DBW 711.

All soil parameters had non significant correlation coefficient with grain and straw yield either positive or negative. Grain yield had significant positive correlation coefficient at $1 \%$ level of probability with straw yield (Table 2).

\section{Conclusion}

The data recorded indicate that intercropping of poplar with wheat crop is suitable for soil physico-chemical properties while sole crop was found suitable for grain yield of crop.Under poplar, highest $\mathrm{pH}$ (7.9), EC (0.43 $\left.\mathrm{dSm}^{-1}\right)$, available soil nitrogen $(253.48 \mathrm{~kg} / \mathrm{ha})$, potassium $(219.63 \mathrm{~kg} / \mathrm{ha})$ were achieved with UP-2572 while organic carbon (1.07\%) and available soil phosphorus $(22.72 \mathrm{~kg} / \mathrm{ha})$ were attained with DBW-711. It was found that there was not a much difference in the production of grain yield of wheat when it was grown with poplar ranging from 24.3 to $41.3 \mathrm{q} / \mathrm{ha}$ as compared to open system varied from 26.7 to $45.3 \mathrm{q} / \mathrm{ha}$ under different wheat varieties.So, instead of sole crop we can adopt combination of arable crop and forest tree species (agroforestry) to enrich soil nutrients and to protect environment and forest trees.

\section{REFERENCES}

Antonio, C. and Gama-Rodrigues (2011). Soil organic matter, nutrient cycling and biological dinitrogen-fixation in agroforestry systems.Agroforestry Systems.81: 191193.

Bernier, B. (1984).IEA/ ENFOR joint report. Canadian Forestry Service, Department of Environment, Ottawa, 
Ontario, Canada, pp. 46.

Garrity, D.P. (2004). Agroforestry and the achievement of the Millenium Development Goals.Agroforestry Systems, 61: 5-17.

Gupta, M.K. and Sharma, S.D.(2009). Effect of tree plantation on soil properties, profile morphology and productivity index: poplar in Yamunanagar district of Hariyana. Annals of Forestry, 17(1): 43-70.

Hymavathi, H.N., Kandhya, A.K. and Patil, L.P. (2010). Beneficial effects of multiple plantations in agroforestry systems. Indian Forester, 4: 465-475.

Jackson, M.L. (1967). Soil Chemical Analysis. Constable, London, $498 \mathrm{pp}$.

Kumar, B.M. (2006). Agroforestry: the new old paradigm for Asian food security. J. Tropical Agriculture,44(1-2): 114.

National Forest Policy. (1988). Department of Environment, Forests \& Wildlife. Government of India Ministry of Environment and Forests. New Delhi.

Newaj, R., Dar, S.A., Bhargava, M.K., Yadav, R.S. and Ajit. (2007).Effect of management practices on growth of white siris (Albizzia procera), grain yield of intercrops, weed population and soil fertility changes in agrisilvi- culture system in semi-arid India. Indian J. of Agricultural Sciences, 77 (7): 403-407.

Prasad, J.V.N.S., Korwar, G.R., Rao, K.V., Mandal, U.K., Rao, C.A.R., Rao, G.R., Ramakrishna, Y.S., Venkateswarlu, B., Rao, S.N., Kulkarni, H.D., Rao, M.R. (2010). Tree row spacing affected agronomic and economic performance of Eucalyptus-based agroforestry in Andhra Pradesh, Southern India. Agroforestry Systems. 78, 253-267.

Puri, S. and Nair, P.K.R.(2004). Agroforestry research for development in India: 25 years of experiences of a national program. Agroforestry Systems.61, 437-452.

Sarvade, S., Mishra, H.S., Kaushal Rajesh, Chaturvedi Sumit and Tewari Salil.(2014). Wheat (Triticumaestivum L.) yield and soil properties as influenced by different agrisilviculture systems of tarai region, Northern India. International Journal of Bio-resource and Stress Management, 5(3):350-355.

Sarvade, S., Mishra, H.S., Rajesh Kaushal, SumitChaturvedi, SalilTewari and Jadhav, T.A.(2014). Performance of wheat (TriticumaestivumL.) crop under different spacings of trees and fertility levels. African Journal of Agricultural Research, 9(9): 866-873. 